\title{
Can Extrinsic Reward Lead to Better Performance? Evidence From CEO Pay
}

\author{
Ying Hong \\ Fordham University \\ Xuguang Guo \\ Cal Poly Pomona
}

\begin{abstract}
The relationship between CEO extrinsic reward and firm performance is of great importance from both scholarly and practical perspectives. This study used the COMPUSTAT dataset tracing CEOs and their firm performance over twenty years. The results indicate that both CEO pay and company profit in the previous year had positive effects on company profit in the current year. In addition, there was a moderating effect of previous year's company profit on the relationship between CEO pay in the previous year and company profit in the current year, in such a way that the effect of CEO pay on future company profit was more positive for less profitable companies. Furthermore, we found a curvilinear relationship between CEO pay and company profit, indicating that excessive CEO compensation was detrimental to company profit. Future research and implications are discussed.
\end{abstract}

Keywords: extrinsic reward, organizational performance, executive compensation, motivation

\section{INTRODUCION}

The issue of CEO compensation has gained increasing public attention in recent years due to the discrepancy between the high CEO pay and the job loss and pay cut being experienced by the rank-and-file workers during the financial crisis (Economist, 2013) and the pandemic (Shapiro, 2021). The public frequently protests that CEO pay is excessive and disproportionate to the performance of company and the earnings of the rank-and-file workers. Part of the reason is that many companies tend to benchmark the market by offering CEO pay above the midpoint, which inevitably created a "race to the top" (Groysberg, Abbott, Marino, \& Aksoy, 2021). As such, the society at large and academic researchers alike are very intrigued by the issue of pay for performance of CEOs - whether there is a significant relationship between company performance and CEO compensation. Much academic literature accumulated in this area draws on the agency theory, which suggests that CEOs as agents of the company are self-serving and thus, incentives should be used to align their interests with those of the company's (Fama \& Jensen, 1983; Jensen \& Meckling, 1976). A meta-analysis of the studies of CEO compensation found that although firm performance was positively associated with CEO pay (accounting for less than $5 \%$ of the variance in CEO pay), its effect was less pronounced than indicators of firm size, which accounted for more than $40 \%$ of the variance in CEO pay (Tosi, Werner, Katz, \& Gomez-Mejia, 2000). Summative reviews of the literature on CEO compensation suggest that other determinants of CEO compensation also include criteria, governance, and other contingencies (Barkema \& Gomez-Mejia, 1998). 
Although the society at large is less concerned about the reverse of this relationship - whether higher CEO compensation leads to higher company performance in the future - it is a critical consideration for the shareholders, and for the corporate boards in making the decisions for CEO compensation. Are organizations wasting their money by paying their CEO handsomely? Is there a tipping point as to the costeffectiveness of high CEO pay? Does high CEO pay work better for some organizations than others? These questions are important to consider for both theoretical and practical reasons. This is what this study intends to address.

Previous studies using different datasets and methodologies have often generated inconsistent conclusions about the causality between CEO compensation and company performance (Devers, Cannella Jr, Reilly, \& Yoder, 2007). This could be due to the contingencies or contextual variables that may affect the relationship between CEO compensation and company performance. The current study, therefore, aims to contribute to a better understanding of this relationship by using recent longitudinal data and examining the boundary conditions.

First, much of the cumulated research that examined the CEO compensation and company performance relationship was conducted over decades ago (Leonard, 1990). Given that the organizational practices and governmental regulations of CEO compensation evolved considerably over the past decades, it is timely to revisit this relationship using more recent data to determine the effect of CEO compensation on company performance. In the current study, we analyzed the data from COMPUSTAT over the recent two decades (from 1992 to 2012) to examine the relationship between CEO compensation and the next year's company performance. The results from this study provide an update to the empirical findings a few decades ago.

Second, the majority of the previous research on the performance outcomes of CEO compensation has used cross-sectional data (Devers et al., 2007). This has inevitably limited our ability to understand the temporal order of CEO pay versus organizational performance; thus, it becomes difficult to disintegrate the "pay for performance" question and the "pay leading to performance" proposition. In this study, we conducted analyses of a panel dataset using a fixed-effect model and a one-year time lag between CEO compensation and organizational performance. As such, we focus particularly on the effect of CEO pay on company performance of the next year.

Third, as discussed above, contingent variables exist which could have an impact on the relationship between CEO compensation and company performance. In this study, we examine two contingency effects. First, different levels of organizational profitability present different degrees of risks, in that less profitable companies provide CEOs with lower income and job security (Bloom \& Milkovich, 1998). To compensate for this risk differential, and to more effectively attract and retain highly capable CEOs to turnaround the organization, we expect that less profitable companies may benefit more from offering competitive compensation to the CEOs. Second, the effectiveness of competitive CEO pay in improving organizational performance may also depend on the level of CEO pay. Previous research has suggested that overpaying CEOs is often associated with overpaying other managers at lower levels of the organizations as well; and that a large differential between the pay at the top versus lower levels of the organization tends to lead to perceptions of injustice (Wade, O'Reilly, \& Pollock, 2006). Both of these consequences are detrimental to the organizational performance. As such, we also contribute to a better understanding of CEO compensation by examining the boundary conditions under which high CEO pay will be associated with high organizational performance. This helps shed light on the inconsistent conclusions that were drawn from previous CEO compensation research.

\section{THEORIES AND HYPOTHESES}

The outcome of interest in this study is organizational profit, which is an accountancy-based performance measure and one of the most important and frequently used indicators for firm performance (Wall, Michie, Patterson, Wood, Sheehan, Clegg, \& West, 2004). To understand how firms maximize their profit, researchers have advanced myriad models of determinants of firm profitability (Slade, 2004). Models originating from the field of industrial organization emphasize either the market structure or market share as the principal determinant of profitability; scholars from financial economics focuses on a firm's risk 
class; organizational researchers, however, tend to view firm profitability as a combined result of various factors within an organization such as organizational practices and climate. All of these perspectives concur in that there is a certain degree of continuity in terms of firm profitability.

The resource-based view of competitive advantage, rooted in structure-conduct-performance paradigm from industrial organization, suggests that it is the valuable and inimitable assets within the firm that make firms competitive and successful (Barney, 1991). Such valuable and inimitable resources may include both external factors as well as internal dynamics, both of which are critical to the survival and growth of an organization. Given that these resources are valuable, rare, inimitable, and nonsubstitutable, the competitive advantages that are generated from such resources are often sustainable over time (Barney, 1991). Therefore, companies that are capable of generating high profits for a given year are very likely to be profitable in the following business cycle as well because of its unique resources generated both internally and externally.

Hypothesis 1. Company profit of the previous year has a positive impact on company profit of the current year.

Controlling for company's profitability of the previous year, what this study intends to understand is whether variation in CEO compensation in a given year explains variance in company profitability of the following year. Theories and empirical studies of extrinsic compensation have suggested inconsistent effects of financial rewards. On one hand, hundreds of studies have shown that various forms of financial rewards, when implemented appropriately, can effectively motivate individual performance (BackesGellner \& Pull, 2013), including that of the CEO's. Different forms of variable pay, such as piece rate, commission, and bonus for individuals, gain sharing and goal sharing for groups, as well as organizational performance-based pay such as stock ownership and stock options for employees and executives, have been widely applied in organizations to encourage the employees to exert their greatest effort in achieving higher performance. In a article published by the Society of Human Resource Management, it has been estimated that more than $80 \%$ of companies around the world are employing some forms of variable pay programs (Miller, 2010).

On the other hand, despite the general acknowledgement of the value of financial rewards by researchers and the common practice of using financial rewards to stimulate individual performance by practitioners, a group of researchers suggest the opposite effect of financial incentives on performance, arguing that financial incentives are morally wrong and practically ineffective (Deci, Koestner, \& Ryan, 1999). These opponents of financial rewards propose that extrinsic rewards externalize individuals' locus of control, by rendering individuals to attribute their effort and achievement to the extrinsic rewards rather than their intrinsic motivation, thus they reduce the self-determination and intrinsic reward of the work (interest in the task), and subsequently decrease both individual and organizational performance.

In reality, extrinsic and intrinsic rewards are difficult to be separated from each other. Financial incentive is a key form of recognition for individual achievements. When pay is implemented properly, the highly paid individuals are equally likely, if not more likely, to enjoy their work than those lowly-paid individuals. Indeed, previous studies have found that although individual bonus did not bear a significant relationship with work performance, individual-based pay was positively related to work performance, which was partially mediated by intrinsic motivation (Kuvaas, 2006). This suggests that if individuals are paid competitively and then money is taken off the table, they are equally, or even more likely, to experience intrinsic motivation and display high performance.

In this study, we examine the effect of extrinsic rewards by focusing on the incentive pay of CEOs of the S\&P 500 companies. The CEOs of S\&P 500 companies are presumably the most elite individuals in the business world. The intrinsic rewards for the S\&P 500 CEOs should all peak at the highest level, by having the utmost levels of autonomy (the freedom to make decisions regarding their work), task variety (the number of different tasks they do every day), task significance (the impact of their decisions on the organization and the society at large), task identity (the opportunity to conduct a task in its entirety), and self-generating feedback (the performance of the organization which they have a decisive influence on) 
(Hackman \& Oldham, 1976). Therefore, a higher level of CEO pay may only present additional extrinsic reward, not intrinsic reward. Drawing on theories and research on extrinsic rewards and individual/CEO performance, we expect that higher CEO pay will be associated with higher organizational performance based on the following reasons.

On one hand, the positive effect of CEO compensation on company profit could be explained from a human capital perspective. Several theoretical frameworks land support to such an explanation. According to the efficiency wage theory (Kreps, 1997), higher compensation offered to CEOs will enable firms to attract more and better-qualified individuals to compete for the position and therefore reduce the chance of an adverse selection (by selecting an incapable CEO or a CEO who does not fit in the organization), and increase the probability of hiring a CEO with the highest level of human capital. Additionally, when CEO pay is relatively high, the cost for the CEO to leave the firm would be astronomical as well. Thus, high CEO pay also reduces the possibility of CEO turnovers. Likewise, based on signaling theory (Spence, 1973), offering high CEO pay signals to the CEO candidates that the firm highly values top talents, which in return allows the organization to obtain a larger and better pool of qualified candidates to select from and retain. Additionally, the expectancy theory (Vroom, 1964) suggests that the probability of receiving high pay in the coming years also has influences on CEO's decision to stay at or to depart from the firm. All these theories in common suggest that firms offering high CEO compensation are more likely to acquire and retain more capable CEOs. Likewise, the human capital theory (Jackson \& Schuler, 1995) highlights the value of individual knowledge, skills, abilities, and competencies for the organization, which are often accompanied by a tremendous amount of investment and reinvestment from the firm to its employees. Thus, high compensation is required for organizations to induce CEO applicants to continuously develop valuable human capital. Additionally, with compensative compensation, CEOs are also more likely to exert their social capital, in terms of utilizing their advice contacts who are capable of offering valuable insight to organizational decisions (Mcdonald, Khanna, \& Westphal, 2008). Taken together, better candidates tend to be attracted, selected, developed, and retained by more highly paid positions.

On the other hand, high CEO compensation also contributes to high performance of the organization by augmenting their motivation to excel. Equity theory (Adams, 1963) suggests that individuals compare their inputs (such as human capital and effort)/outputs (such as pay) ratio with equivalent others within and outside of their firms, e.g., for CEOs, the equivalent others are often CEOs at comparable firms. When the inputs/outputs ratio appears to be less advantageous than that of equivalent others, a sense of inequity will arise, which can be detrimental to the individual motivation at work. As such, as a coping mechanism to reduce the cognitive dissonance over the fact that their pay is not commensurate with that of equivalent others, underpaid individuals are likely to reduce the perceived inequity by cutting their inputs at work, or by exiting the organization (Cowherd \& Levine, 1992). In the case of CEOs, however, they are less likely to be engaged in behaviors such as reducing their effort at work because of their strong needs for achievements; thus, they are often found to use quitting as a coping strategy (Fong, Misangyi, \& Tosi, 2010). The reverse is true for competitively paid CEOs (Fong et al., 2010). Indeed, using a compensation equation that estimates the CEO's market value and data from COMPUSTAT, Fong et al. (2010) found that overpaid CEOs tended to reduce the dissonance between pay and their input by exerting more effort to enhance firm performance (which aligns with CEO's power and achievement motivational needs), whereas underpaid CEOs were more likely to exit the organization, or increase firm size (which indirectly increases future compensation).

Likewise, social exchange theory (Blau, 1964) indicates that individuals reciprocate the higher pay that they receive from their firms with continuous efforts to achieve high performance at work. When CEOs are highly compensated, they are more likely to feel obligated to enhance organizational performance as an exchange for being well paid. Expectancy theory similarly argues that the probability of receiving high pay in the coming years affects the CEO's assessment of the instrumentality of exerting more efforts at work (Vroom, 1964). Consequently, high compensation received by CEOs will likely lead to their expectation that increasing their performance will be further rewarded in the future. Relatedly, reinforcement theory posits that being compensated well encourages individuals to maintain good performance (Luthans \& Stajkovic, 1999; Skinner, 2011). Goal-setting theory also indicates that monetary rewards can result in high 
individual self-efficacy to set specific and more challenging goals in the future and as such, exert more effort to attain those goals than when they otherwise would not (Latham, Locke, \& Fassina, 2002; Locke \& Latham, 1990). In a meta-analysis of 39 laboratory, simulated experiment, and field studies, individual financial incentives were shown to have a significant relationship with performance quantity with an effect size of .34 (Jenkins Jr, Gupta, Gupta, \& Shaw, 1998). Interestingly, this meta-analysis didn't find a significant effect of individual financial incentives on performance quality. Nonetheless, this does not dismiss the value of financial rewards in soliciting more work effort, particularly in terms of quantitative productivity.

Given the enhanced human capital and motivation that are brought by higher compensation of CEOs, the question that remains for the link between CEO pay and firm performance is: do CEOs have control over firm performance? In other words, can a CEO make a difference in firm performance by utilizing the superior human capital or exhibiting elevated motivation? This is indeed a critical condition for CEO performance to be translated into firm performance. Researchers who are proponents of CEO's control over firm performance have argued that compared to lower-level employees, CEOs have the utmost control and impact on firm performance. A CEO can influence firm performance by formulating a collective purpose for the organization, instill values that guide organizational activities, create a culture that is shared among the employees, and initiate strategic changes that are critical for ensuring organizational efficiency, adaptation, and human capital (Mackey, 2008; Yukl, 2008). Other researchers, however, suggest that the effect of leadership often depends on the situation, thus CEOs may not have substantial control over organizational performance in the presence of many exogenous factors (Lieberson \& O'Connor, 1972; Vroom \& Jago, 2007). In reviewing the previous studies conducted between 1972 and 2001, the effect of CEOs on firm performance was considered to be modest, with the estimated effect of CEOs explaining between $5.7 \%$ and $14.7 \%$ of variance in firm ROA (Mackey, 2008). Using panel data between 1992 and 2002 from COMPUSTAT, however, Mackey (2008) found an estimated effect of CEOs explaining as much as $29.2 \%$ of the variance in firm ROA, after restricting the sample to those that had CEO turnovers and CEOs who had worked at more than 1 firm during the 10 years that were studied (these conditions allowed the comparison between CEOs within a company and the comparison of a CEO between companies). Based on the previous theorizing and research, we argue that although the effect size of CEOs' impact on organizational performance varies from study to study, there is considerable evidence that CEOs can apply their human capital and motivation to affect the performance of organizations. Therefore, we propose the following hypothesis:

Hypothesis 2. CEO compensation of the previous year has a positive impact on company profit of the current year.

Although we hypothesize a positive main effect of CEO compensation on next year's company profit, the greater CEO human capital and motivation enabled by high pay will not function equally across organizations; instead, we expect that the effect of CEO pay on company profit will be more salient among less profitable organizations than among more profitable organizations for several reasons. First, the risk level associated with operating a less profitable organization is greater than that of a more profitable organization. Working capital management in the field of financial management suggests that there is an inherent tradeoff between profitability and risk (García-Teruel \& Martínez-Solano, 2007). To increase their profitability, less profitable firms are more likely to need to engage in higher-risk activities. CEOs of less profitable organizations, as a consequence, need to bear more uncertainty in the business environment and deal with more complex decision-making than their counterparts at more profitably organizations in order to turn the organization around into a more profitable cycle. In addition, and more important to CEOs on a personal level, less profitable organizations present a higher level of risk for the CEO's income and employment security as well (Bloom \& Milkovich, 1998). This presents an additional level of uncertainty to the CEO's personal work and life. According to agency theory (Jensen \& Meckling, 1976) and compensating differential theory (Rappaport, 2004), the augmented levels of efforts requirement and increased risks for the CEOs of less profitable organizations require that they be provided with some form 
of insurance, i.e., be paid generously to overcome these undesirable aspects. We therefore expect that high CEO compensation among less profitable organizations will be more effective in generating high organizational performance than high CEO compensation in more profitable organizations. Bloom and Milkovich (1998)'s study found that low-risk organizations tended to provide higher base pay and reduce performance-based pay in order to provide insurance for the executives, and that those high-risk organizations that did the opposite, i.e., utilized greater performance-based pay, in fact introduced a higher level of risks to executives, which jeopardized organizational performance.

Second, the degree of performance difference that a CEO can make is much greater in a less profitable organization than in an already highly profitable organization. As discussed above, less profitable organizations may opt to engage in greater risk taking to increase their profitability, thus affording a greater degree of managerial discretion to their CEOs. Given this potentially greater variance in CEO performance among less profitable organizations, the ability of the organization to utilize competitive compensation as a tool to attract and retain highly competent and motivated CEOs becomes exorbitantly important. As argued above, by offering competitive compensation, less profitable organizations can attract and retain the best CEOs who can effectively enhance organizational performance by formulating a collective purpose for the organization, instilling values that guide organizational activities, creating a culture that is shared among the employees, and initiating strategic changes that are critical for ensuring organizational efficiency, adaptation, and human capital (Mackey, 2008; Yukl, 2008). We therefore expect that it is more instrumental for less profitable organizations to compensate their CEOs competitively than for more profitable organizations.

Hypothesis 3. Company profit will moderate the relationship between CEO compensation in the previous year and current year's company profit in that for less profitable companies, the effect of CEO compensation on company profit will be stronger than that of the more profitable companies.

Although CEO compensation is expected to operate as an extrinsic motivator for CEOs to achieve higher performance for the organization, we argue that the positive effect is not linear. There are several potential pitfalls associated with over-paying the CEO. First, previous research has suggested that organizations that over-pay their CEOs often over-pay other executives and managers at the lower levels of the organization (Carpenter \& Sanders, 2002). It has been estimated that when the CEO of an organization is overpaid by $64 \%$ relative to the market, managers at level 2 are overpaid by $26 \%$, while managers at level 5 are overpaid by $12 \%$ (Wade et al., 2006). This is plausibly because of a consistent pay strategy that is being implemented within the organization, and the over-paid CEO's desire to reduce the magnitude of pay differential in the organization. This pay matching practice may become imperative in situations where many CEOs need to delegate complex responsibilities to the top management team and functional heads in the organizations (Carpenter \& Sanders, 2002). Given the wide spread of over-paid top executives and managers in the organization, it will inevitably incur a significant financial burden on the organization, thus reducing the potential magnitude of the performance increase of the organization that can be brought by a capable and motivated CEO as a result of receiving competitive compensation.

Second, overpaid CEOs are likely to cast a negative influence on lower-level managers' morale, as shown in Wade et al. (2006)'s study, which found that CEO overpayment was associated with a higher turnover rate at the lower levels of the management rank. More importantly, overpaid CEOs will also trigger employee perceptions of inter-class pay differentials. Inter-class pay equity, measured as the proper inputs and pay ratios among hourly workers and lower level exempt employees compared to those of top management, were shown to be positively related to product quality (Cowherd \& Levine, 1992). Based on social comparison theory (Hill, 1987) and theories of distributive justice (Greenberg, 1990), managers and employees at lower ranks often experience a great contrast of their pay versus the CEO's pay, thus they are likely to experience an intensive feeling of injustice (Wade et al., 2006). This is likely exacerbated by overpaying the CEO in those underperforming organizations. Thus, to the extent that CEO compensation is perceived to be disproportionate to the organization's performance or to the lower-ranked employees' 
compensation, employee perceptions of injustice will develop, which will in turn result in high employee turnover and low performance of the organization.

Based on the above reasons, we propose that there is a tipping point of paying the CEOs competitively, in that overpaying the CEOs will no longer lead to higher financial performance of the organization, but cause harm to firm performance instead.

Hypothesis 4. The correlation between CEO compensation in the previous year and company profitability in the current year is curvilinear. When CEO compensation is excessive, its positive effect for future company profitability is diminishing.

\section{METHODS}

The data of this study were obtained from COMPUSTAT, which contains detailed information of firm demographics, capital structure, and performance for S\&P 500 companies. It also provides compensation data for the five highest paid executives. Our study covers data from 1992 to 2012.

The following fixed-effects models applied to the empirical analyses:

$$
\begin{aligned}
& y_{i t}=\beta_{1} \text { pay }_{i t-1}+\beta_{2} \text { profit }_{i t-1}+\beta_{3}\left(\text { pay }_{i t-1} * \text { profit }_{i t-1}\right)+\beta_{4} \text { Pay }_{i t-1}^{2} \sum \beta_{q} \text { control }_{i t}+ \\
& \alpha_{i}+S_{t}+u_{i t}
\end{aligned}
$$

where $y_{i t}$ is the net profit for company $i$ in year $t$; pay $y_{i t-1}$ is the executive pay for company $i$ in year $t-1$; prof $_{i t-1}$ is the net profit for company $i$ in year $t-1 ; \alpha_{i}$ is the unknown intercept for company $i$; $S_{t}$ is the unknown intercept for year $t$; $u_{i t}$ is the error term.

COMPUSTAT is a panel dataset. It typically includes information for a CEO and the company for multiple years. $\alpha_{i}$ represents the effects of firm-specific variables such as corporate culture or norms. It is not feasible for one research project to include or observe all potential firm-specific variables. Those missing variables in $\alpha_{i}$, however, could lead to biased results if they are correlated with any of the independent variables included in the regressions (Stock \& Watson, 2003). Using firm fixed-effects can effectively control for the effects of the potential unobserved variance under $\alpha_{i}$ (Bergh, 1993; Somaya, Williamson, \& Lorinkova, 2008; Stock \& Watson, 2003). Likewise, the year fixed-effects can control for the unobserved variances within specific years under $S_{t}$ (Such as economic cycles, natural disaster, or political events).

The CEO pay is measured as total CEO compensation last year including salary, short-term and longterm incentives, and other taxable incomes. We cannot estimate temporal relationship from CEO pay to firm performance in the same year, because CEOs' pay is usually based on their annual performance. Instead, by using one-year lag, we can examine how the CEO pay of a given year affects future firm performance. In addition, we also include corporate profit last year as a key independent variable and the moderator. It reflects a company's potential profitability. A profitable firm has its organizational capital and human capital to continue its legacy regardless the CEO's ability and effort. Other control variables include firm asset, employment of the firm, CEO age, CEO gender (equal to 1 if male; 0 otherwise) and CEO tenure.

Companies with only one or two-years observations are excluded from the sample. Those companies have limited or no information for previous years, thus they are not suitable for the firm fixed-effects model. 


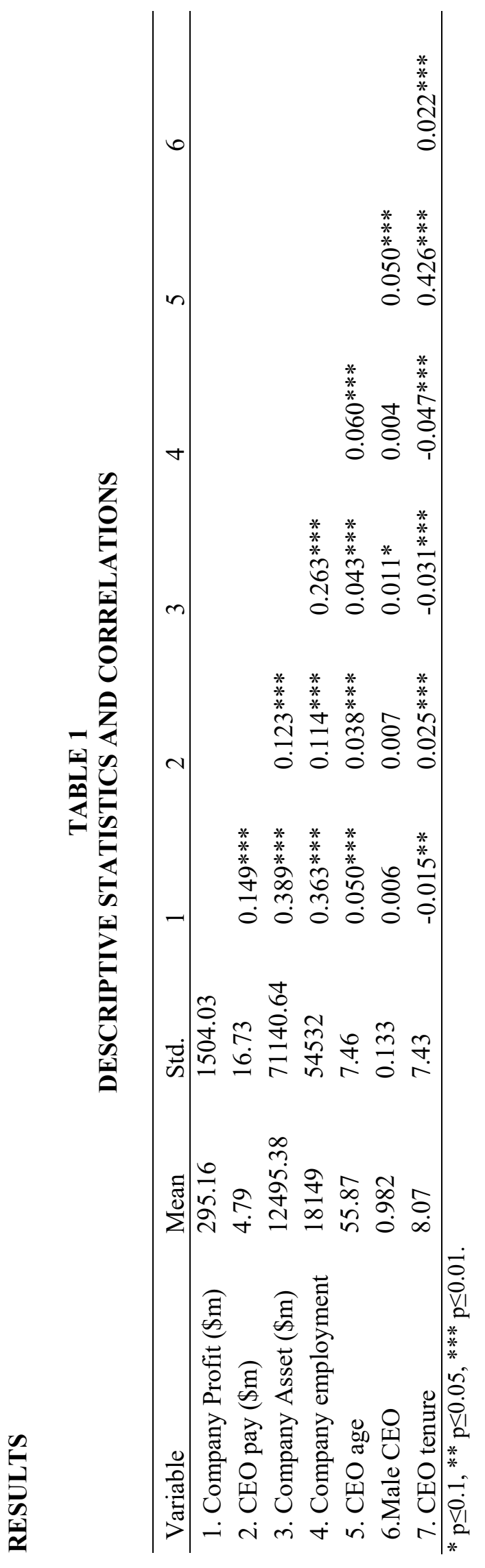


Table 1 presents means, standard deviations, and correlations among studied variables. CEO pay is positively and significantly associated with company profit $(r=.15, p<.001)$, company asset $(r=.12, p<$ $.001)$, and number of employees $(r=.11, p<.001)$, as well as CEO age $(r=.04, p<.001)$ and tenure $(r=$ $.03, p<.001)$. The average pay for CEO in our sample was 4.70 million; and the average corporate profit was \$295.18 million. More than 98 percent of the CEOs were male. It explains why the correlations of gender are not significant with three out of five variables. The total observations for the sample are 24,924.

TABLE 2

THE IMPACT OF CEO COMPENSATION ON COMPANY PROFIT

\begin{tabular}{|l|l|l|l|l|}
\hline & Model 1 & Model 2 & Model 3 & Model 4 \\
\hline Company Asset & $0.003^{* * *}$ & $9.59 \mathrm{e}-4 * * *$ & $8.78 \mathrm{e}-4 * * *$ & $8.63 \mathrm{e}-4 * * *$ \\
\hline Company Employment & $(2.05 \mathrm{e}-4)$ & $(1.97 \mathrm{e}-4)$ & $(1.97 \mathrm{e}-4)$ & $(1.97 \mathrm{e}-4)$ \\
\hline & $0.012^{* * *}$ & $0.008^{* * *}$ & $0.008^{* * *}$ & $0.008^{* * *}$ \\
\hline CEO Age & $(3.70 \mathrm{e}-4)$ & $(3.56 \mathrm{e}-4)$ & $(3.56 \mathrm{e}-4)$ & $(3.57 \mathrm{e}-4)$ \\
\hline & -3.027 & -2.204 & -2.217 & -2.095 \\
\hline Male CEO & $(1.918)$ & $(1.805)$ & $(1.803)$ & $(1.802)$ \\
\hline & 121.491 & 84.770 & 82.350 & 80.027 \\
\hline CEO Tenure & $(89.432)$ & $(84.164)$ & $(83.072)$ & $(84.045)$ \\
\hline & 3.135 & 1.756 & 1.725 & 1.464 \\
\hline CEO Pay last year & $(1.961)$ & $(1.805)$ & $(1.844)$ & $(1.845)$ \\
\hline & & $1.479 * * *$ & $2.328 * * *$ & $4.705 * * *$ \\
\hline Company Profit last year & & $(0.428)$ & $(0.445)$ & $(0.740)$ \\
\hline & & $0.372^{* * *}$ & $0.403 * *$ & $0.404 * * *$ \\
\hline Last year (pay*profit) & & $(0.007)$ & $(0.008)$ & $(0.008)$ \\
\hline & & & $-8.11 \mathrm{e}-4 * * *$ & $-8.67 \mathrm{e}-4 * * *$ \\
\hline Last year (pay*pay) & & & $(1.15 \mathrm{e}-04)$ & $(1.16 \mathrm{e}-4)$ \\
\hline & & & & $-0.0026^{* * *}$ \\
\hline Constant & & & & $(6.55 \mathrm{e}-4)$ \\
\hline & $532.085^{* * *}$ & $388.795^{* * *}$ & $375.670^{* * *}$ & $365.004 * * *$ \\
\hline R-square & $(153.329)$ & $(144.325)$ & $(144.177)$ & $(144.152)$ \\
\hline$\Delta$ R-square & 0.195 & 0.441 & 0.446 & 0.448 \\
\hline \# of observations & & $0.246 * * *$ & $0.004 * * *$ & $0.02 * * *$ \\
\hline The d & 24924 & 24924 & 24924 & 24924 \\
\hline
\end{tabular}

1. The data are from Compustat and cover companies in North America between 1992 and 2012

2. Company fixed-effects and year effects are included in all three models

3. ${ }^{*} \mathrm{p} \leq 0.1, * * \mathrm{p} \leq 0.05, * * * \mathrm{p} \leq 0.01$.

The regression results are presented in Table 2. Firm fixed-effects and year-fixed effects are included in all four models. Model 1 includes only control variables. Not surprisingly, larger firms (with more assets and more employees) are more profitable than smaller companies $(b=.003$ and $b=.012$, respectively, $p<$ $.001)$. Other CEO characteristics (age, gender, and tenure) are not significantly related to corporate profitability $(b=-3.03, b=121.49$, and $b=3.14$, respectively, $p>.05)$.

Two independent variables were added in Model 2: CEO pay of last year and corporate profit of last year. The coefficients for both variables are significant. The coefficient for profit last year is $.37(\mathrm{p}<.001)$. It indicates that for every $\$ 1$ increase in company profit in a given year, it is associated with 0.37 more profit for the next year, controlling for other factors. Hypothesis 1 is supported. The coefficient for CEO pay is $1.48(\mathrm{p}<.001)$. For a CEO who is paid $\$ 1$ more in a given year, the company generates $\$ 1.48$ more in profit in the following year. Hypothesis 2 is confirmed. The fixed-effects models eliminated the biases from firm-specific and time-specific factors. The coefficients are consistent to different firms across 
different years. The R-square is changed from .195 in Model 1 to .441 . Overall, the results are robust in Model 2.

The moderating effect of company profit last year on the relationship between CEO compensation and firm profitability is examined in Model 3 . The coefficient for the interaction between CEO pay last year and profit in the current year is negative and significant $(b=-.0008, p<.001)$. The magnitude of the moderating effect is illustrated in Figure 1. Thus Hypothesis 3 is illustrated: CEOs from less profitable companies are more motivated to perform by receiving high compensation than CEOs from more profitable companies.

FIGURE 1

\section{MODERATING EFFECT PF COMPANY PROFIT LAST YEAR ON THE RELATIONSHIP BETWEEN CEO PAY AND COMPANY PROFIT (BASED ON MODEL 3 OF TABLE 2)}

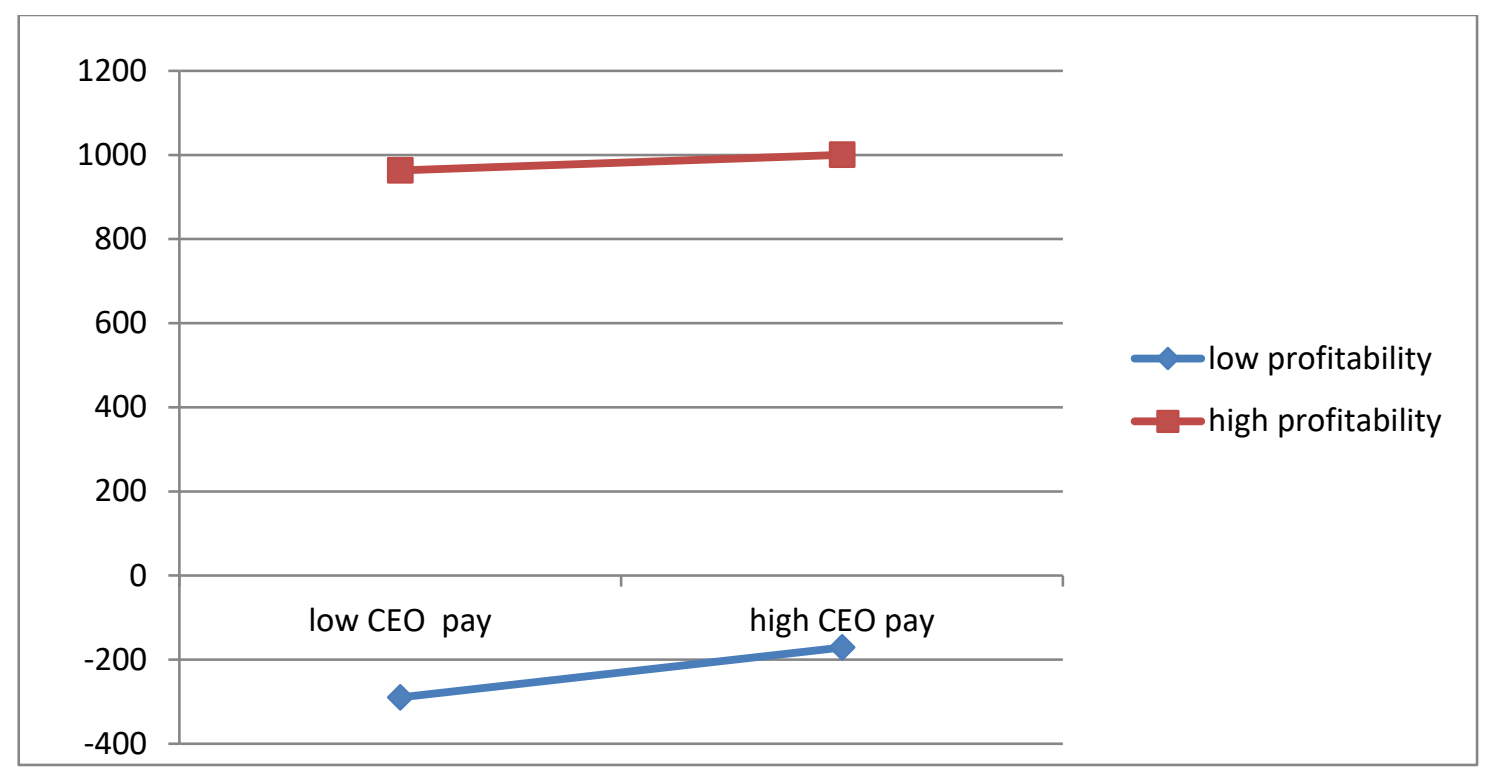

Polynomial regression is applied in Model 4 to estimate if the correlation between CEO pay and corporate performance is quadratic instead of linear. The coefficient for the square of CEO pay last year is negative and significant $(b=-.0026, p<.001)$, which supports the Hypothesis 4. Using the result from Module 4 in Table 2, Figure 2 plots the correlation between CEO pay last year and company profit in the current year when keeping other variables constant at the value of their means. As expected, CEO pay is positively with company profit before it reaches its peak, where the correlations turn negative. The U shape curve suggests that when CEO pay becomes excessive, the motivation effect of high CEO pay is diminishing. 


\section{FIGURE 2 \\ CURVILINEAR RELATIONSHIP BETWEEN CEO PAY AND COMPANY PROFIT (\$MILLION)}

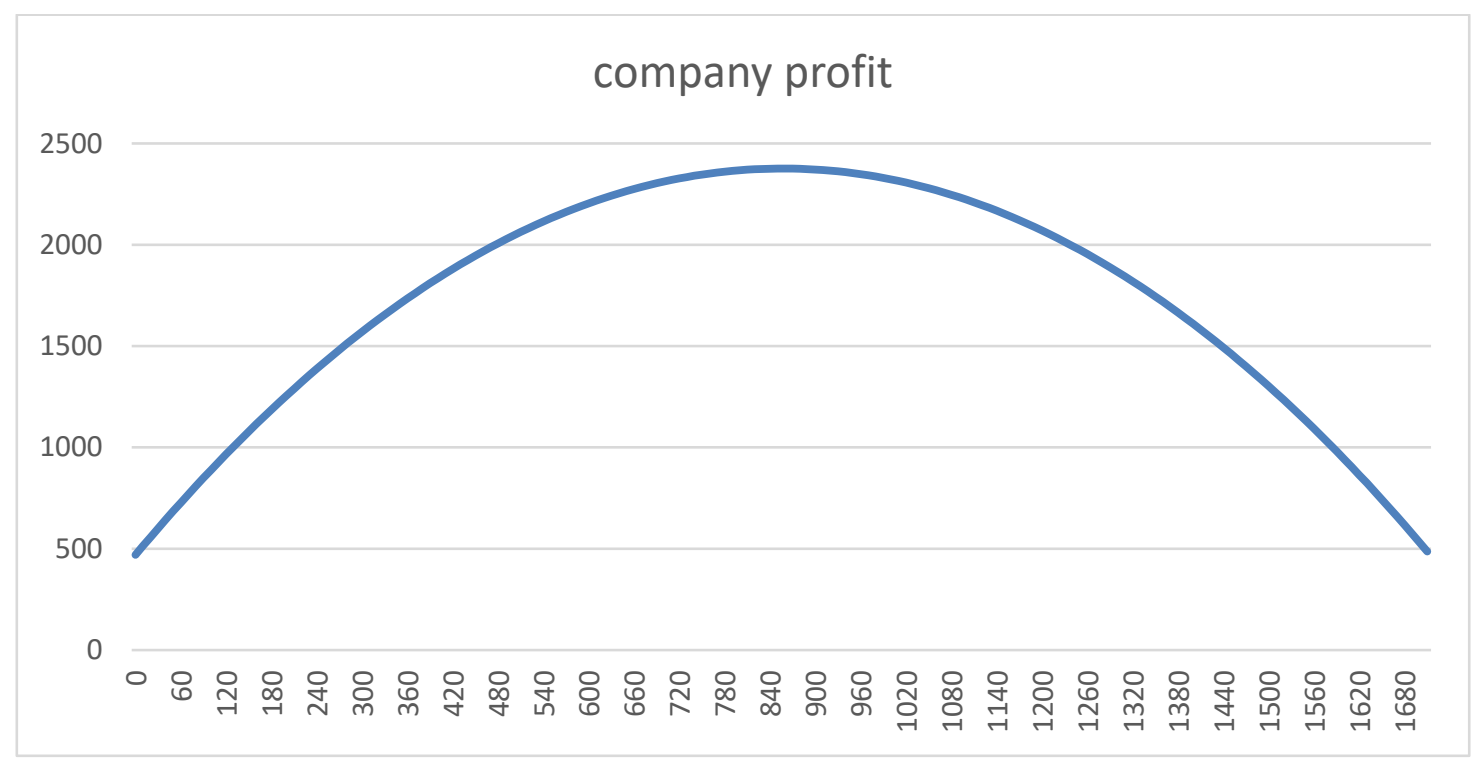

Note:

1. The figure is based on the regression results from Model 4 of Table 2.

2. The horizontal axis presents CEO pay last year (\$million); the vertical axis measures company profit in the current year (\$million)

3. We present the correlation between CEO last year and company profit in the current year and keep other variables constant at the values of their means.

\section{DISCUSSION}

Over the past several decades, the majority of CEO compensation research has borrowed from agency theories to understand whether there is "pay for performance" for CEOs, and why CEOs are able to reap more compensation for themselves. CEO compensations frequently feature major news and magazine headlines, particularly those relevant to the shareholders' nonbinding vote for "say on pay" (Economist, 2013). The other way of examining this question, however, is more important from a practical standpoint: that is, what are the consequences of CEO compensation on the organization? The Economist article discussed a controversial case because although the compensation package of John Hammergren, the boss of McKesson, was lucrative, McKesson's share price more than tripled during the 13 years when Mr. Hammergren was in office (Economist, 2013). This presented an extraordinary performance of the company compared to the S\&P 500 index, which only rose $40 \%$ in the same period. An important question then is, to what extent does CEO compensation influence firm performance? This paper thus examines the effects of CEO compensation on firm performance, and the boundary conditions on the relationship, using data of the S\&P 500 companies from COMPUSTAT.

We found that although extrinsic rewards are considered detrimental to individuals' intrinsic motivation and performance in certain situations (Deci \& Ryan, 1985), more extrinsic rewards for CEOs were associated with higher financial performance of S\&P 500 companies in the year after. This aligns with the arguments made by proponents of individual extrinsic rewards, which suggests that individual extrinsic rewards would not impair intrinsic motivation to the extent that organizational attraction, selection, and attrition processes are taken into consideration; as such, individuals who are motivated by different incentive mechanisms all fit into the proper organizations and positions (Fang \& Gerhart, 2011). This unique dataset from COMPUSTAT addresses the issue of intrinsic motivation in that CEOs of S\&P 500 
companies tend to have high power and achievement needs, and enjoy a high level of intrinsic motivation from their jobs. As such, higher extrinsic rewards are unlikely to detriment their intrinsic motivation on their jobs. On the contrary, higher extrinsic rewards will enable the organization to attract the best talents and motivate them to exert their best effort on improving the organization's performance.

The results also suggested that the effect of CEO compensation on next year's financial performance was not equal across organizations. Instead, less profitable companies benefited more from offering competitive CEO compensation in turning the company around. Although less profitable companies may be less prone to offer competitive CEO compensation due to their financial constraints (Leonard, 1990), our results indicated that competitive CEO compensation was particularly important for these organizations to overcome the excess risks that the CEOs were exposed to when taking over low performing companies. Other factors that need to be taken into consideration include organizations' size, region, strategy, cash flow, culture, and risk appetite (Groysberg et al., 2021). We encourage future research to further disentangle the underlying factors that render competitive CEO compensation at low performing companies especially important, such as assessing the perceived risks in both personal lives as well as at work by the CEOs, and investigating the performance variance between high performing and low performing organizations.

Last but not the least, we found interesting, curvilinear relationship between CEO compensation and firm financial performance. As noted by Leonard (1990; p. 13), "An executive who earns tens of millions of dollars in pay per year provokes a certain critical regard no matter how efficient his operations". An excessive level of executive pay is likely to incur perceptions of injustice from lower levels of the organizations. Additionally, over paying CEOs could also reveal other structural or governance issues that are inherent in the organization, such as the practices of also overpaying other managers in the organizations, or a high level of cronyism that is rampant in the organization (Brick, Palmon, \& Wald, 2006). This has important implications for compensation committees when designing the compensation packages for the CEOs, in that cautions should be exercised when balancing the urge to attract and retain the best talent at the top with the need to maintain a fair and productive work environment.

\section{LIMITATIONS AND FUTURE RESEARCH}

Although the usage of the COMPUSTAT dataset has its merit (e.g., panel data, large sample size, representative sample of the large organizations population), it also suffers from several limitations. First, there have been debates on how to operationalize organizational performance (Devers, Cannella, Jr., Reilly, \& Yoder, 2007; Wall et al, 2004). There are a variety of company measures, which could be taken into consideration such as market-based measures of shareholder value, rather than accountancy-based performance measures such as profit (Russo \& Fouts, 1997; Wall et al, 2004). We adopted a profit-based measure to be consistent with the approach taken in previous studies (Mackey, 2008). Research suggests that S\&P companies most commonly use a combination of multiple metrics, such as profits (91\%) and revenues (49\%), as well as non-financial indicators such as strategic and individual metrics (Groysberg et al., 2021). We would encourage future research to examine other indicators to organizational performance to validate the hypotheses.

Second, researchers have insinuated that organizational performance is influenced not only by the CEOs, but also by numerous other factors that could not be controlled for in a single study (Devers et al., 2007). For example, previous studies have shown that organizational risks dictate the composition of executive compensation, which has a direct implication for firm performance (Bloom \& Milkovich, 1998). Besides CEO compensation, the top management team's compensation was equally, if not more, important in determining firm performance (Carpenter \& Sanders, 2002). We have employed fixed-effects to effectively control for the impact of other variances and focus on the impacts of two factors: CEO pay and company profit in the previous year. Future research can incorporate other organizational factors in a single model to disentangle their relative effects on organizational performance.

Lastly, researchers have favored breaking down the types of incentives of the CEO's package over a mixed pay approach (Bloom \& Milkovich, 1998; Devers et al., 2007), given that CEOs may respond to different compensation elements differently. One distinction is between fixed pay and variable pay. 
Previous research has suggested that base pay was more instrumental in soliciting individuals' intrinsic motivation to perform than contingent bonus (Kuvaas, 2006) and was more effective among high-risk organizations than performance-based incentives (Bloom \& Milkovich, 1998). Nonetheless, the counter argument is that too high a base pay will insulate CEOs from the effect of poor performance, which is why currently $82 \%$ of the CEO pay of the Russell 3000 companies are variable pay (Groysberg et al., 2021). Another consideration is short-term vs. long-term incentives as well as cash vs. equity. Stock options were shown to motivate CEOs to achieve long-term performance of the organization by taking greater risks to invest in R\&D, capital spending, and large-scale acquisitions, but at the expense of showing little concern for downside possibilities at the same time (Sanders \& Hambrick, 2007). Nonetheless, long-term equity is also subject to uncontrollable future volatility and market performance. Comparatively, the United States employ a much greater proportion of long-term incentives (75\%) than Europe and Australia (36\%) as well as Asia, where long-term incentives are almost nonexistent, and the majority of compensation relies on base salary (63\%) (Groysberg et al., 2021). We call for future studies to replicate our model by disintegrating different elements of the CEO compensation package.

\section{CONCLUSIONS}

The relationship between CEO extrinsic reward and firm performance has garnered substantial interest from both scholars and the general public. This study used the COMPUSTAT dataset tracing CEOs and their firm performance over two decades. The results indicate that CEO compensation in the previous year had a positive effect on company profit of the current year. In addition, the effect of CEO compensation on company profit was more pronounced for less profitable companies. Furthermore, we found a curvilinear relationship between CEO pay and company profit, indicating that excessive CEO compensation was detrimental to company profit. These findings provide empirical evidence to the existing debate regarding if and how CEO pay affects firm performance. They also offer implications for compensation committees when designing the right compensation packages for the CEOs. The results in the study should be replicated among rank-and-file employees to understand how they respond to financial rewards. Higher compensation can motivate individuals and lead to better performance, but excessive pay may cause reverse impacts.

\section{REFERENCES}

Adams, J.S. (1963). Toward an understanding of inequity. Journal of Abnormal and Social Psychology, 67, 422-436.

Backes-Gellner, U., \& Pull, K. (2013). Tournament compensation systems, employee heterogeneity, and firm performance. Human Resource Management, 52, 375-398.

Barkema, H.G., \& Gomez-Mejia, L.R. (1998). Managerial compensation and firm performance: A general research framework. Academy of Management Journal, 41, 135-145.

Barney, J. (1991). Firm resources and sustainable competitive advantage. Journal of Management, 17, 99-129.

Bergh, D.D. (1993). Don't "waste" your time! The effects of time series errors in management research: The case of ownership concentration and research and development spending. Journal of Management, 19, 897-914.

Blau, P. (1964). Exchange and power in social life. New York: Wiley.

Bloom, M., \& Milkovich, G.T. (1998). Relationships among risk, incentive pay, and organizational performance. Academy of Management Journal, 41, 283-297.

Brick, I.E., Palmon, O., \& Wald, J.K. (2006). CEO compensation, director compensation, and firm performance: Evidence of cronyism? Journal of Corporate Finance, 12, 403-423.

Carpenter, M.A., \& Sanders, W.M.G. (2002). Top management team compensation: The missing link between CEO pay and firm performance. Strategic Management Journal, 23, 367-375. 
Cowherd, D.M., \& Levine, D.I. (1992). Product quality and pay equity between lower-level employees and top management: An investigation of distributive justice theory. Administrative Science Quarterly, 37, 302-320.

Deci, E.L., Koestner, R., \& Ryan, R. (1999). A meta-analytic review of experiments examining the effects of extrinsic rewards on intrinsic motivation. Psychological Bulletin, 125, 627-668.

Deci, E.L., \& Ryan, R.M. (1985). The general causality orientations scale: Self-determination in personality. Journal of Research in Personality, 19, 109-134.

Devers, C.E., Cannella, A.A., Jr., Reilly, G.P., \& Yoder, M.E. (2007). Executive compensation: A multidisciplinary review of recent developments. Journal of Management, 33, 1016-1072.

Fama, E.F., \& Jensen, M.C. (1983). Separation of ownership and control. Journal of Law and Economics, $26,301-325$.

Fang, M., \& Gerhart, B. (2011). Does pay for performance diminish intrinsic interest? The International Journal of Human Resource Management, 23, 1176-1196.

Fong, E.A., Misangyi, V.F., \& Tosi, H.L. (2010). The effect of ceo pay deviations on CEO withdrawal, firm size, and firm profits. Strategic Management Journal, 31, 629-651.

García-Teruel, J.P., \& Martínez-Solano, P. (2007). Effects of working capital management on SME profitability. International Journal of Managerial Finance, 3, 164-177.

Greenberg, J. (1990). Organizational justice: Yesterday, today, and tomorrow. Journal of Management, $16,399-432$.

Groysberg, B., Abbott, S., Marino, M.R., \& Aksoy, M. (2021). Compensation Packages That Actually Drive Performance. Harvard Business Review, 99(1), 102-111.

Hackman, J.R., \& Oldham, G.R. (1976). Motivation through the design of work: Test of a theory. Organizational Behavior \& Human Performance, 16, 250-279.

Hill, C.A. (1987). Affiliation motivation: People who need people... but in different ways. Journal of Personality and Social Psychology, 52, 1008-1018.

Jackson, S.E., \& Schuler, R.S. (1995). Understanding human resource management in the context of organizations and their environments. In M.R. Rosenweig, \& L.W. Porter (Eds.), Annual review of psychology (pp. 237-264). Palo Alto, Calif: Annual Reviews, Inc.

Jenkins, G.D., Jr., Gupta, N., Gupta, A., \& Shaw, J.D. (1998). Are financial incentives related to performance? A meta-analytic review of empirical research. Journal of Applied Psychology, 83, 777-787.

Jensen, M.C., \& Meckling, W.H. (1976). Theory of the firm: Managerial behavior, agency costs and ownership structure. Journal of Financial Economics, 3, 305-360.

Kreps, D.M. (1997). Intrinsic motivation and extrinsic incentives. American Economic Review, 87, 359.

Kuvaas, B. (2006). Work performance, affective commitment, and work motivation: The roles of pay administration and pay level. Journal of Organizational Behavior, 27, 365-385.

Latham, G.P., Locke, E.A., \& Fassina, N.E. (2002). The high performance cycle: Standing the test of time. In S. Sonnentag (Ed.), The psychological management of individual performance. A handbook in the psychology of management in organizations (pp. 201-208). Chichester: Wiley.

Leonard, J.S. (1990). Executive pay and firm performance. Industrial \& Labor Relations Review, 43, 1329.

Lieberson, S., \& O'Connor, J.F. (1972). Leadership and organizational performance: A study of large corporations. American Sociological Review, 37, 117-130.

Locke, E.A., \& Latham, G.P. (1990). A theory of goal setting and task performance. Englewood Cliffs, NJ: Prentice Hall.

Luthans, F., \& Stajkovic, A.D. (1999). Reinforce for performance: The need to go beyond pay and even rewards. Academy of Management Executive, 13, 49-57.

Mackey, A. (2008). The effect of ceos on firm performance. Strategic Management Journal, 29, 13571367. 
Mcdonald, M.L., Khanna, P., \& Westphal, J.D. (2008). Getting them to think outside the circle: Corporate governance, ceos' external advice networks, and firm performance. Academy of Management Journal, 51, 453-475.

Miller, S. (2010). Companies worldwide rewarding performance with variable pay. Society of Human Resource Management. Retrieved from https://www.shrm.org/resourcesandtools/hropics/compensation/pages/variableworld.aspx

Rappaport, J. (2004). Why are population flows so persistent? Journal of Urban Economics, 56, 554-580.

Sanders, W.G., \& Hambrick, D.C. (2007). Swinging for the fences: The effects of ceo stock options on company risk taking and performance. Academy of Management Journal, 50, 1055-1078.

Shapiro, A. (2021, February 10). New study calls CEO pandemic pay cuts 'window dressing. Yahoo Finance.

Skinner, B.F. (2011). About behaviorism. New York: Random House LLC.

Somaya, D., Williamson, I. O., \& Lorinkova, N. (2008). Gone but not lost: The different performance impacts of employee mobility between cooperators versus competitors. Academy of Management Journal, 51, 936-953.

Spence, M. (1973). Job market signaling. The Quarterly Journal of Economics, 87(3), 355-374.

Stock, J.H., \& Watson, M.W. (2003). Introduction to econometrics. Boston: Pearson.

Tosi, H.L., Werner, S., Katz, J.P., \& Gomez-Mejia, L.R. (2000). How much does performance matter? A meta-analysis of ceo pay studies. Journal of Management, 26, 301-339.

Vroom, V.H. (1964). Work motivation. New York: Wiley.

Vroom, V.H., \& Jago, A.G. (2007). The role of the situation in leadership. American Psychologist, 62, $17-24$.

Wade, J.B., O’Reilly, I.I.I.C.A., \& Pollock, T.G. (2006). Overpaid ceos and underpaid managers: Fairness and executive compensation. Organization Science, 17, 527-544.

Yukl, G. (2008). How leaders influence organizational effectiveness. Leadership Quarterly, 19, 708-722. 